\title{
Evaluation of Learning Programs at Bali State Polytechnic (BSP)
}

\author{
I Nyoman Gunung ${ }^{1}$, I K Darma ${ }^{2}$ \\ Mechanincal Engineering Department \\ Politeknik Negeri Bali \\ Bali, Indonesia \\ ${ }^{1}$ nyomangunung@pnb.ac.id, ${ }^{2}$ ketutdarma@pnb.ac.id
}

\begin{abstract}
This evaluation study aims to determine the profile of the implementation of learning programs in PNB in terms of components: 1) context, 2) input, 3) process, 4) products, and 5) linkages of learning program products with context, input and process components. The study was conducted at the Bali State Polytechnic in 2017/2018 . Object of research Student, Lecturer, Administrative Staff, and Head of department / Chair of the Study program. Research subjects were recruited proportionally stratified random sampling. The size of the sample was determined using the Krejcie table and Harry King's Nomogram based on a 5\% error of 241 people. The research variable includes four main function variables for evaluating the implementation of learning programs. Data were collected with documentation and questionnaires and analyzed quantitatively and qualitatively. The results of the analysis show that the implementation of the learning program at the Bali State Polytechnic when viewed from the components: 1) contex is effective, 2) input is effective, 3 ) process is effective, 4) product is ineffectiveis, and 5) the relationship between contex, input, process, and product is quite effective.
\end{abstract}

Keywords: program evaluation, polytechnic learning, CIPP model, effectiveness

\section{INTRODUCTION}

Law No. 12 of 2012 concerning Higher Education clause 59 subsection (5), that a Polytechnic is a College that organizes vocational education in various groups of Science and / or Technology and if it meets the requirements, polytechnics can hold professional education. The third part of paragraph 2 of clause 16 subsection (1) states vocational education is a Higher Education diploma program that prepares students for work with certain applied skills to an applied undergraduate program.Polytechnic is a form of higher education that organizes vocational education in various clusters of Science and / or Technology, preparing students for jobs with certain applied skills to applied bachelor programs. To become a graduate of the Polytechnic, education is needed with a learning system that is designed appropriately in accordance with the development of the times and the rapid development of technology.

BSP is one of the vocational education institutions in Bali. In its operations BSP has a vision and mission. The current vision is to become a leading vocational higher education institution that produces professional graduates with international competitiveness in 2025, while one of its missions is to produce reliable personnel who are oriented to market needs in the field of Engineering and Commerce with Tourism as superior.

Preparing students to take the world of work, BSP in the learning process using a package system, namely a learning system that requires students to take all courses programmed in each period of the school year, in accordance with the subjects in the curriculum of each department. The education package system has the following characteristics: 1) students take all courses that are programmed and must graduate in each semester according to the applicable regulations, 2) the success of student studies is determined based on academic achievement and attendance at lectures, and 3) number of hours per week for each subject is determined on the basis of the target abilities and skills to be achieved.

Evaluation is one component of the planning and implementation process of a program [1]. It is not complete if an activity is not followed by an evaluation effort. Evaluation is a systematic effort to collect, compile, and process data, facts and information with the aim of concluding the value, usefulness, performance and consequences of organizations, institutions, programs and or work units and using these conclusions in the decision making and planning process [2], [4].

When this has happened, education reform as a whole. The process of learning activities which were initially centered by the lecturers became focused on students by prioritizing student activities in learning. In general, the teaching and learning situation at the tertiary level in Indonesia today mostly still follows an old pattern that is centered on institutions or lecturers. Similarly, what happened in BSP, lecturers tended to teach face to face using the lecture method. The assessment of BSP students towards the learning process is less satisfactory, because the lecturers often use conventional learning methods (lectures) and rarely do orientation in learning [5].

Education and teaching are said to be successful if the changes that appear to students must be as a result of the learning process they experience [6]. At least as a result of carrying out the teaching program designed by the lecturer. Assessment of learning programs is carried out in a balanced manner and carried out simultaneously or thoroughly. Whereas the assessment of learning outcomes, solely without assessing the process, tends to see student factors as scapegoats of 
educational failure. In the unlikely event that student failure is caused by the weakness of teaching and learning process where the lecturer is in charge. The effectiveness of program implementation is not only seen from the student factors (internal) but other factors (external) must be considered as well. For example lecturers, curriculum, facilities and infrastructure, teaching and learning activities on campus, practical activities in the laboratory and work practices in industry, industrial relations with the campus and other factors.

On the basis of these changes and developments, the implementation of learning in PNB needs to be assessed through an evaluative study to see aspects of productivity, efficiency and effectiveness of ongoing learning. Changes to the Polytechnic curriculum from conventional to competencybased curriculum and developed referring to the Indonesian National Qualifications Framework indicate a need for the need to assess the implementation of learning. In order to improve the quality of graduates, the system of planning and administering learning must be planned and implemented properly and systematically.

In connection with this fact it is necessary to evaluate the learning program to determine the level of effectiveness. Program evaluation is an indispensable demand for the development of training, learning and empowerment programs [7]. However good the planning and implementation of the program, without evaluation, the program cannot be known for its success [8]. It is not complete if an activity is not followed by an evaluation effort. Success and failure of a program needs to be assessed from the objectives and indicators that have been determined by program planning. Through this evaluation information will be obtained in the form of problems that need improvement and improvement as they should.

In order to improve a program, modification, termination (forwarding of a program) especially the learning program is being carried out, it needs an effort to comprehensively, systematically and diagnostically evaluate the planning and implementation of lecturers in BSP. Evaluation of the implementation of these program activities in the past has never been carried out partially or comprehensively. Efforts to carry out an evaluation of the program's activities on planning and implementation are an urgent need. Moreover, evaluation efforts will produce information that can be used to make a decision. Evaluation of this quality improvement program will see whether its implementation of learning has referred to national education standards required in the National Standards of Higher Education [9]

The implementation of this evaluation study uses an evaluation model developed by Stufflebeam in 1971, which is about Context, Input, Process, and Product (CIPP) (from Ward Mitchell Cates, 1990). The CIPP model looks at four dimensions: context, input, process and product [10]. The CIPP evaluation model is seen as being strategically used to improve the quality of educational programs [11].A survey conducted on Training and Development Members in the United States found that the CIPP model preferred over other evaluation models [4]

The evaluation results of the CIPP model can be used as a basis for decision making in four types of decisions, namely:
(1) planning (which affects the selection of goals and objectives of the activity), (2) structuring (which determines the optimal strategy and design procedures for achieving goals), (3) implementation (which provides tools for implementing existing programs and program improvements), and (4) recycling (whether an activity needs to be continued, changed, or stopped)

Evaluation of context will produce information about needs (to what extent there is a deviation between what is expected and what is realized through an activity program). Evaluation of inputs emphasizes the provision of information about the strengths and weaknesses of the strategies and procedures of the activities chosen in an effort to realize the stated goals. The evaluation of the process emphasizes on "what" activities are carried out in the program, "who" when who is appointed as the person in charge of the program, when when will the activity be completed. While the evaluation of product emphasizes the extent to which results have been achieved in accordance with the desired goals, and whether an activity needs to be stopped, continued, improved and so on. Evaluation of the product has the purpose of linking information about the results with the goals, setting, carrying capacity, and predetermined processes [11-14].

The CIPP model program evaluation succeeded in showing that the suitability of the implementation of the social studies program in SMP / MTs in Bima City with the standard of the education process [15]. Evaluation of the CIPP model is able to show that the implementation of the Chemistry learning program at SMA 3 Watansoppeng 3 is viewed from the context, input, process, and product aspects that are in accordance with process standards, but in certain fields such as chemistry learning motivation needs to be improved [16]. Evaluation of the CIPP model was also able to show that the implementation of the Industrial Practice program in relation to Dual System Education in SMK N 1 Susut in terms of context, input, process and product variables was very ineffective. It is recommended: (1) schools involve industry in planning, implementing, monitoring and evaluating the industrial work practice program. (2) the industry must conduct competency tests and professional tests to encourage students to improve their competence in the course of work preparation after graduating from vocational high school, (3) the Bangli Regency Youth and Sports Education Agency helps in providing infrastructure facilities that support the implementation of teaching and learning in schools [17].

The evaluation results will give a lot of clues about what has been done and what has not been done, whether the learning process is in accordance with the learning planning that has been designed, whether the material given by the lecturer can be detected by students, and in accordance with the standard contents of the implementation of learning in BSP. All information obtained will be used as a reference for efforts to improve the quality of education in BSP. Therefore, learning is one of the elements in the system of preparing midwifery workforce in BSP needs to be studied with an evaluative research. The focus of evaluation includes learning planning, implementation of the learning process, and assessment and no further assessment results. 
This evaluation study aims to determine the profile of the implementation of learning in BSP in terms of components: 1) context; 2) Input; 3) process; 4) product, and 5) the relevance of learning program products with context, input and process component.

\section{Methodology}

This research is an evaluation research, using the CIPP Evaluation Model (Context, Input, Process, Product). Evaluation subjects, namely the academics of the Bali State Polytechnic in 2017/2018. The study was conducted at the Bali State Polytechnic. Data collection is done using questionnaires, observation, and document analysis. The data analysis technique used is quantitative descriptive. The evaluation phase can be described as follows.

Evaluation phase of the context of learning implementation, covering aspects of learning planning, which in detail focuses on the types of objectives formulated and the proportion of each domain that is determined.

The stages of input evaluation in the implementation of learning include the problem of providing facilities and infrastructure for learning in PNB. The carrying capacity of learning focuses more on aspects of the availability of study room facilities for the recovery, availability and utilization of educational media which include reference books or textbooks, laboratory equipment and other media used, the quality of the lecturers, syllabi and Learning Implementation Plans.Process evaluation stages of learning implementation, including material planning, media use, method use, principal steps taken in learning, and learning outcome assessment.Product evaluation stages of learning implementation include the value of student learning outcomes and their relationship to the components of context, input, and process.

\section{RESULTS AND DISCUSSION}

This evaluation study was conducted on 241 respondents including the Chair of the Department and Study Program, staff staff, Lecturers, and Students. There are four main problems evaluated, namely: 1) contex, 2) input, 3) process and 4) the results of the learning program (product). The description of the distribution of the characteristics of the measurement results of each variable is presented in a summary of descriptive analysis in the following Table I.
TABLE I. SUMmary OF DESCRIPTIVE ANALYSIS OF VARIABLE, CONTEXT, INPUT, PROCESS AND PRODUCT MEASUREMENT RESULTS.

\begin{tabular}{|c|r|r|r|r|}
\hline Statistik & Contex & Input & Process & Product \\
\hline $\mathrm{N}$ & 241 & 241 & 241 & 241 \\
\hline Mean & 93,32 & 111,83 & 72,39 & 53,21 \\
\hline Median & 93,00 & 111,00 & 72,00 & 52,00 \\
\hline Mode & 89 & 102 & 68 & 52 \\
\hline Std. Deviation & 6,559 & 8,594 & 5,069 & 3,746 \\
\hline Variance & 43,020 & 73,850 & 25,696 & 14,034 \\
\hline Range & 34 & 51 & 26 & 19 \\
\hline Minimum & 76 & 84 & 59 & 44 \\
\hline Maximum & 110 & 135 & 85 & 63 \\
\hline
\end{tabular}

In Table I, it can be explained that the context variable tends to be the measurement results centered at 93.32. This means that on average, the overall measurement score of the respondents is 93.32, the midpoint is 93.0, the most commonly obtained is 89 , the smallest is 76 , the highest is 110 , the distance between the highest and the smallest is 34 , the average deviation of the measurement from the average 6,559 , and variation 43,02 .

The results of measurement of input variable tend to focus at 111.83 . That is, on average the measurement results overall score of respondents is 111.83 , the midpoint is 111 , the most commonly obtained is 102 , the smallest is 84 , the highest is 135 , the distance between the highest and the smallest is 51 , the average deviation of measurement results from an average of 8.594 , and a variation of 73.85 .

The measurement results of the process variable tend to focus at 72.39. That is, on average the overall score of the respondent's score is 72.39 , the midpoint is 72 , the most commonly obtained is 68 , the smallest is 59 , the highest is 85 , the distance between the highest and the smallest is 26 , the average deviation of the measurement results from average of 5,069 , and variation of 25,696 .

The results of the measurement of product variables tend to focus on 53.21. This means that on average the overall score of the respondent is 53.21, the midpoint is 52.0, most often gets 52 , the smallest is 44 , the highest is 63 , the distance between the highest and the smallest is 19, the average deviation from the average 3,746, and variation 14,034.

The results of the context variable measurement of the respondents indicate that the highest score that can be achieved is 110 and the lowest is 76 from the ideal highest and lowest score of 110 and 22. The average measurement score is 93.32. The proportion of achieving an ideal maximum score of $84.8 \%$ and categorized as very high. Frequency distribution results of the context variable measurements are presented in Table II. 
TABle II. FReQuency Distribution of ConteXt Variable Measurement Results

\begin{tabular}{|c|c|c|c|c|c|c|c|}
\hline \multirow{2}{*}{ Inter.Class } & \multirow{2}{*}{ Mid.Point } & \multirow[b]{2}{*}{$\begin{array}{l}\text { Obs. } \\
\text { Freq. }\end{array}$} & \multirow[b]{2}{*}{$\begin{array}{c}\text { Rel.Freq. } \\
(\%)\end{array}$} & \multirow{2}{*}{$\begin{array}{l}\text { Cumv. } \\
\text { Freq. }\end{array}$} & \multirow{2}{*}{$\begin{array}{c}\text { Cumv. } \\
\text { Freq. } \\
(\%)\end{array}$} & \multicolumn{2}{|c|}{$\begin{array}{l}\text { Categ. } \\
\text { Freq }\end{array}$} \\
\hline & & & & & & $\begin{array}{c}\geq \\
\mathbf{5 0} \\
(+)\end{array}$ & $\begin{array}{c}< \\
50 \\
(-)\end{array}$ \\
\hline $76-79$ & 77,5 & 1 & 0,004 & 1 & 0,004 & 0 & 1 \\
\hline $80-83$ & 81,5 & 12 & 0,050 & 13 & 0,054 & 0 & 12 \\
\hline $84-87$ & 85,5 & 25 & 0,104 & 38 & 0,158 & 0 & 25 \\
\hline 88-91 & 89,5 & 70 & 0,290 & 108 & 0,448 & 0 & 70 \\
\hline $92-95$ & 93,5 & 39 & 0,162 & 147 & 0,610 & 29 & 10 \\
\hline 96-99 & 97,5 & 53 & 0,220 & 200 & 0,830 & 53 & 0 \\
\hline $100-103$ & 101,5 & 20 & 0,083 & 220 & 0,913 & 20 & 0 \\
\hline 104-107 & 105,5 & 15 & 0,062 & 235 & 0,975 & 15 & 0 \\
\hline 108-111 & 109,5 & 6 & 0,025 & 241 & 1,000 & 6 & 0 \\
\hline \multicolumn{2}{|c|}{ Sum } & 241 & & & & 123 & 118 \\
\hline
\end{tabular}

In Table II, it can be seen that the results of the reduction of context variables are most clustered at the 5th interval. The number of frequency categories (+) and (-) is 123 and 118, $(+)>$ frequency $(-)$. Therefore, the implementation of the learning program in PNB seen from the context variables can be concluded table 3.2, it can be seen that the results of the reduction of context variables are most clustered at the 5th interval. The number of frequency categories (+) and (-) is 123 and $118,(+)>$ frequency $(-)$. Therefore, the implementation of the learning program in PNB seen from the context variables can be concluded.
The results of the measurement of the input variables on the respondents indicate that the highest score that can be achieved is 135 and the lowest is 84 from the highest and lowest ideal scores of 135 and 27. The average score of the measurement results is 111.83 . The achievement percentage of the maximum score is $82.8 \%$ and is categorized as high. Frequency distribution results from the measurement of input variables are presented in Table III.

TABLE III. FreQuency Distribution of InPUT Variable MEASUREMENT RESUlts

\begin{tabular}{|c|c|c|c|c|c|c|c|}
\hline \multirow{2}{*}{$\begin{array}{l}\text { Inter. } \\
\text { Class }\end{array}$} & \multirow{2}{*}{$\begin{array}{l}\text { Mid. } \\
\text { Point }\end{array}$} & \multirow[b]{2}{*}{$\begin{array}{l}\text { Obs. } \\
\text { Freq. }\end{array}$} & \multirow[b]{2}{*}{$\begin{array}{c}\text { Rel.Freq. } \\
(\%)\end{array}$} & \multirow{2}{*}{$\begin{array}{l}\text { Cumv. } \\
\text { Freq. }\end{array}$} & \multirow{2}{*}{$\begin{array}{c}\text { Cumv. } \\
\text { Freq. } \\
(\%)\end{array}$} & \multicolumn{2}{|c|}{$\begin{array}{c}\text { Categ. } \\
\text { Freq }\end{array}$} \\
\hline & & & & & & $\begin{array}{c}\geq \mathbf{5 0} \\
(+)\end{array}$ & $\begin{array}{c}<50 \\
(-)\end{array}$ \\
\hline $84-89$ & 86,5 & 1 & 0,007 & 1 & 0,004 & 0 & 1 \\
\hline 90-95 & 92,5 & 2 & 0,014 & 3 & 0,012 & 0 & 2 \\
\hline 96-101 & 98,5 & 15 & 0,107 & 18 & 0,075 & 0 & 15 \\
\hline $102-107$ & 104,5 & 55 & 0,393 & 73 & 0,303 & 0 & 55 \\
\hline $108-113$ & 110,5 & 82 & 0,586 & 155 & 0,643 & 73 & 9 \\
\hline $114-119$ & 116,5 & 36 & 0,257 & 191 & 0,793 & 36 & 0 \\
\hline $120-125$ & 122,5 & 34 & 0,243 & 225 & 0,934 & 34 & 0 \\
\hline 126-131 & 124,5 & 10 & 0,071 & 235 & 0,975 & 10 & 0 \\
\hline $132-137$ & 134,5 & 6 & 0,043 & 241 & 1 & 6 & 0 \\
\hline Sum & & 241 & 1,721 & & & 159 & 82 \\
\hline
\end{tabular}

In Table III, it can be seen that the results of the measurement of input variables are mostly clustered at the 5th interval in the average class. The number of frequency categories (+) and (-) is 159 and 89 , frequency (+)> frequency
(-). Therefore, the implementation of learning programs in PNB in terms of input variables can be concluded effectively.

Measurement of process variables includes the implementation of teaching and learning processes in the 
classroom and in the laboratory. The results of the measurement of process variables on the respondents indicate that the highest score that can be achieved is 85 and the lowest is 59 from the highest and lowest score of 85 and 17. The average score of the measurement results is 72.39 . The percentage of achieving a maximum score of $85.2 \%$ and high category. Frequency distribution results from the process variable measurement are presented in Table IV.

TABle IV. Frequency Distribution of Process Variable Measurement Results.

\begin{tabular}{|c|c|c|c|c|c|c|c|}
\hline \multirow{2}{*}{$\begin{array}{l}\text { Inter. } \\
\text { Class }\end{array}$} & \multirow{2}{*}{$\begin{array}{l}\text { Mid. } \\
\text { Point }\end{array}$} & \multirow[b]{2}{*}{$\begin{array}{l}\text { Obs. } \\
\text { Freq. }\end{array}$} & \multirow[b]{2}{*}{$\begin{array}{c}\text { Rel.Freq. } \\
(\%)\end{array}$} & \multirow{2}{*}{$\begin{array}{l}\text { Cumv. } \\
\text { Freq. }\end{array}$} & \multirow{2}{*}{$\begin{array}{c}\text { Cumv. } \\
\text { Freq. } \\
(\%)\end{array}$} & \multicolumn{2}{|c|}{$\begin{array}{l}\text { Categ. } \\
\text { Freq }\end{array}$} \\
\hline & & & & & & $\begin{array}{c}\geq 50 \\
(+)\end{array}$ & $\begin{array}{c}<50 \\
(-)\end{array}$ \\
\hline $59-61$ & 60 & 4 & 0,0166 & 4 & 0,017 & 0 & 4 \\
\hline $62-64$ & 63 & 4 & 0,0166 & 8 & 0,033 & 0 & 4 \\
\hline $65-67$ & 64 & 16 & 0,0664 & 24 & 0,1 & 0 & 16 \\
\hline $68-70$ & 69 & 80 & 0,332 & 104 & 0,432 & 0 & 80 \\
\hline $71-73$ & 72 & 57 & 0,2365 & 161 & 0,668 & 47 & 10 \\
\hline 74-76 & 75 & 33 & 0,1369 & 194 & 0,805 & 33 & 0 \\
\hline $77-79$ & 80 & 20 & 0,083 & 214 & 0,888 & 20 & 0 \\
\hline $80-82$ & 83 & 18 & 0,0747 & 232 & 0,963 & 18 & 0 \\
\hline $83-85$ & 84 & 9 & 0,0373 & 241 & 1 & 9 & 0 \\
\hline Sum & & 241 & & & & 127 & 114 \\
\hline
\end{tabular}

In table IV, it can be seen that the results of the management process variable are mostly clustered at the 3rd interval. The number of frequencies categories $(+)$ and $(-)$ is 127 and 114 , frequency $(+)>$ frequency $(-)$. Therefore, the implementation of learning programs in PNB on process variables can be concluded to be effective.

The results of the measurement of the product variables on the respondents showed that the highest score that could be achieved was 63 and the lowest was 44 from the highest and lowest lowest score of 65 and 13. The average measurement score was 53.21. The proportion of achieving a maximum score of $81.9 \%$ and categorized as very high. Frequency distribution results of measurement of product variables are presented in Table V.

TAble V. Frequency Distribution of Product Variable Measurement Results.

\begin{tabular}{|c|c|c|c|c|c|c|c|}
\hline \multirow{2}{*}{$\begin{array}{l}\text { Inter. } \\
\text { Class }\end{array}$} & \multirow{2}{*}{$\begin{array}{l}\text { Mid. } \\
\text { Point }\end{array}$} & \multirow[b]{2}{*}{$\begin{array}{l}\text { Obs. } \\
\text { Freq. }\end{array}$} & \multirow[b]{2}{*}{$\begin{array}{c}\text { Rel.Freq. } \\
(\%)\end{array}$} & \multirow{2}{*}{$\begin{array}{c}\text { Cumv. } \\
\text { Freq. }\end{array}$} & \multirow{2}{*}{$\begin{array}{c}\text { Cumv. } \\
\text { Freq. } \\
(\%)\end{array}$} & \multicolumn{2}{|c|}{$\begin{array}{l}\text { Categ. } \\
\text { Freq }\end{array}$} \\
\hline & & & & & & $\begin{array}{c}\geq \mathbf{5 0} \\
(+)\end{array}$ & $\begin{array}{c}<50 \\
(-)\end{array}$ \\
\hline $44-46$ & 45 & 7 & 0,029 & 7 & 0,029 & 0 & 7 \\
\hline $47-49$ & 48 & 20 & 0,083 & 27 & 0,112 & 0 & 20 \\
\hline $50-52$ & 51 & 102 & 0,4232 & 129 & 0,535 & 0 & 102 \\
\hline $53-55$ & 54 & 58 & 0,2407 & 187 & 0,776 & 43 & 15 \\
\hline $56-58$ & 57 & 30 & 0,1245 & 217 & 0,9 & 30 & 0 \\
\hline $59-61$ & 60 & 17 & 0,0705 & 234 & 0,971 & 17 & 0 \\
\hline $62-64$ & 63 & 7 & 0,029 & 241 & 1 & 7 & 0 \\
\hline Sum & & 241 & & & & 97 & 144 \\
\hline
\end{tabular}

In Table $\mathrm{V}$, it can be seen that the results of the most variable product clustering at the 4 th interval in the average class. The number of frequency categories (+) and (-) is 97 and 144, frequency $(+)$ <frequency (-). Therefore, the implementation of learning programs in PNB in terms of product variables is not effective.

\section{CONCLUSION}

Research findings, obtained the following conclusions: the learning program at the Bali State Polytechnic when viewed from the components: 1) contex is effective, 2) input is effective, 3) process is effective, 4) product is ineffectiveis, and 5) the relationship between contex, input, process, and product is quite effective. It is recommended that an increase in the effectiveness of the implementation of learning programs in BSP can be carried out by increasing the effectiveness of the product component through increasing the effectiveness of contex, input, and intensive learning processes. 


\section{ACKNOWLEDGMENTS}

The author would like to thank Directorate Research and Social Service, Ministry of Research,Technology, and Higher Education and Bali State Polytechnic Research and Service Center for financial support, their guidance that this research was successful undertaken.. The author also wishes to respect all lecturers, students who participated in this study for their contributions and anonymous reviewers for valuable comments in this paper.

\section{REFERENCES}

[1] J.C. McDavid and L.R.L. Hawthorn, Program evaluation and performance measurement, USA: SAGE Publications, 2006.

[2] D. K. Sukardi, Evaluasi Program Pendidikan dan Pelatihan. Jakarta: PT. Bumi Aksara, 2014.

[3] E, Foroozandeh,A. Riazi and F. Sadighi, "TEFL program evaluation at master's level in Iran", TELL,vol. 2, no.6, pp. 71-100, 2008.

[4] J. C. Galvin,"What can trainers learn from educators about evaluating management training?", Training and Development Journal, vol. 37, no.8, pp. 52-57, 1983.

[5] I. N. Sukra, "Pengembangan Bahan Ajar Bahasa Inggris Berbasis Kompetensi Untuk Mahasiwa Akuntansi Politeknik (tahap analisis kebutuhan)", Jurnal Teknodik, vol.18, no.2, pp. 207-216, 2014.

[6] N. Sudjana, Dasar-dasar Proses Belajar Mengajar. Bandung: Sinar Baru Algensido Offset, 2004.

[7] GAO (US General Accounting Office), Performance measurement and evaluation: Definitions and relationships. Retrieved June, 2013 from http://www.gao.gov/special.pubs, 1998.

[8] Musa, Evaluasi Program Pembelajaran. Bandung: I-PIN Indonesia, 2005.

[9] Kemdikbud, Peraturan Menteri Pendidikan dan Kebudayaan Republik Indonesia nomor 49 tahun 2014 tentang Standar Nasional Pendidikan Tinggi. Jakarta: Kemdikbud, 2014.
[10] D. L. Stufflebem, “The CIPP Model For Evaluation”, J. of Intl. Hanbook of Edu., International Hanbook of Education Kluwer International Hanbook of Educational, vol. 9, (n.d), pp. 31-62, 2003.

[11] G. Zhang, N. Zeller,R. Griffith, D. Metcalf, J. Williams, C. Shea and K. Misulis, "Using the Context, Input, Process, and Product Evaluation Model (CIPP) as a Comprehensive Framework to Guide the Planning, Implementation, and Assessment of Service-learning Programs", Journal of Higher Education Outreach and Engagement, vol. 15, no. 4, 57-83, 2011.

[12] D. L. Stufflebeam, and A. J. Shinkfield, Evaluation theory, models, \& applications. San Francisco, CA: Jossey-Bass, 2007.

[13] A. Suharsimi, Evaluasi Program Pendidikan. Bumi Aksara. Jakarta. Djudju, 2009

[14] Warju, "Educational Program Evaluation using CIPP Model", E-Journal Innovation of Vocational Technology Education (invotec), vol. 12, no, 1, pp. 36-42, 2016.

[15] I. Waluyati, "Evaluasi Program Pembelajaran Ilmu Sosial SMP?MTs di Kota Bima", Jurnal Penelitian dan Evaluasi Pendidikan, vol. 16, no. 1, pp. n.d, 2012.

[16] A. S. Mirwati, dan J. Saludung, " Evaluasi Program Pembelajaran Kimia Pada SMA Negeri 3 Watansoppeng",Riset Assesmen Jurnal Penelitian dan Evaluasi Pendidikan, vol.1, no. 1, pp. 1-8, 2015.

[17] I.K. Suartika, N. Dantes, and I.M. Candiasa, "Studi Evaluasi Program Praktek Kerja Industri (Prakerin) Dalam Kaitannya Dengan Pendidikan Sistem Ganda di SMK Negeri Susut", e-Journal Program Pascasarjana Universitas Pendidikan Ganesha Program Studi Penelitian dan Evaluasi Pendidikan,vol. 3, no.2, n.d, 2013.

[18] G. Zhang, R. Griffith, D. Metcalf, N. Zeller, K. Misulis, D. Shea and J. Williams. "Assessing service and learning of a service-learning program in teacher education using mixed-methods research". Paper presented at the American Education Research Association Annual Conference, San Diego, CA, April 2009. 